\title{
Investigación a través de la fotografía: imágenes del patrimonio cultural en ReA
}

Olga Viñuales Meléndez, María Luisa Loza Azuaga | Área de servicios documentales, Centro de Documentación y Estudios, Instituto Andaluz del Patrimonio Histórico

URL de la contribución <www.iaph.es/revistaph/index.php/revistaph/article/view/4623>

"Las fotografías se valoran porque suministran información.

Dicen qué hay, hacen un inventario. Para los espías, meteorólogos, jueces de instrucción, arqueólogos y otros profesionales de la información, tienen un valor inestimable"

Sontag (2006: 40)

En las últimas décadas Internet y las tecnologías de la información se han convertido en unas potentes herramientas a la hora de acercar la sociedad a la investigación que se genera en los centros públicos y, en nuestro caso, a aquellos enfocados al patrimonio cultural de Andalucía.

En esta labor los documentalistas desempeñan un papel primordial puesto que, entre otras tareas, tienen entre sus manos la de presentar de una forma ordenada los importantes recursos que genera no solo la investigación sino también el quehacer cotidiano de sus instituciones. Fruto de ese trabajo es la puesta a punto de importantes recursos documentales a través de los repositorios digitales.

Como consecuencia de esta estrategia y unido a la necesidad institucional de poner en valor nuestros fondos documentales y gráficos nace el Repositorio de Activos Digitales, ReA, presentado en una anterior contribución a este debate ${ }^{1}$. Dentro de ReA la comunidad "Imágenes del Patrimonio Cultural" es un espacio primordial no solo para el conocimiento del patrimonio por el valor documental que tiene la fotografía, sino también como un instrumento para su gestión, preservación, conservación y difusión.

La documentación fotográfica que se conserva en el repositorio constituye un fondo inestimable para la inves- tigación del patrimonio de Andalucía en todas las áreas y disciplinas relacionadas y un fondo creciente de consulta donde acudir a la hora de conocerlo.

La citada comunidad pone a disposición de toda la sociedad una gran recopilación de documentación gráfica con más de ochenta y cuatro mil imágenes, todas ellas de un gran valor, memoria visual de nuestro patrimonio cultural en la que puede adentrarse no solo a disposición de la sociedad actual sino también de nuestras futuras generaciones.

Esta comunidad se constituye, además, en una importante referencia a la hora de la difusión del patrimonio histórico de Andalucía, canalizando sus contenidos a través de la Guía Digital del Patrimonio Cultural de Andalucía, un ingente proyecto que permite la colaboración de la ciudadanía en su formación.

Las "Imágenes del Patrimonio Cultural" son, además, una fuente de información esencial a la hora de desarrollar una investigación histórica sobre el patrimonio cultural de Andalucía y, en especial, en aquellos procesos de documentación, gestión e intervención sobre un bien cultural, ejercicios profesionales del IAPH, que ha constituido parte del trabajo diario que esta institución, en su recorrido histórico, ha desarrollado.

Parte de este ingente número de imágenes, derivadas de nuestras actuaciones propias, han sido recogidas y compendiadas en el repositorio. A estos fondos hay que sumar aquella otra documentación fotográfica, relacionada con otras responsabilidades de este organismo, como son la formación de los profesionales del patrimonio y aquellas derivadas de la propia actividad social 


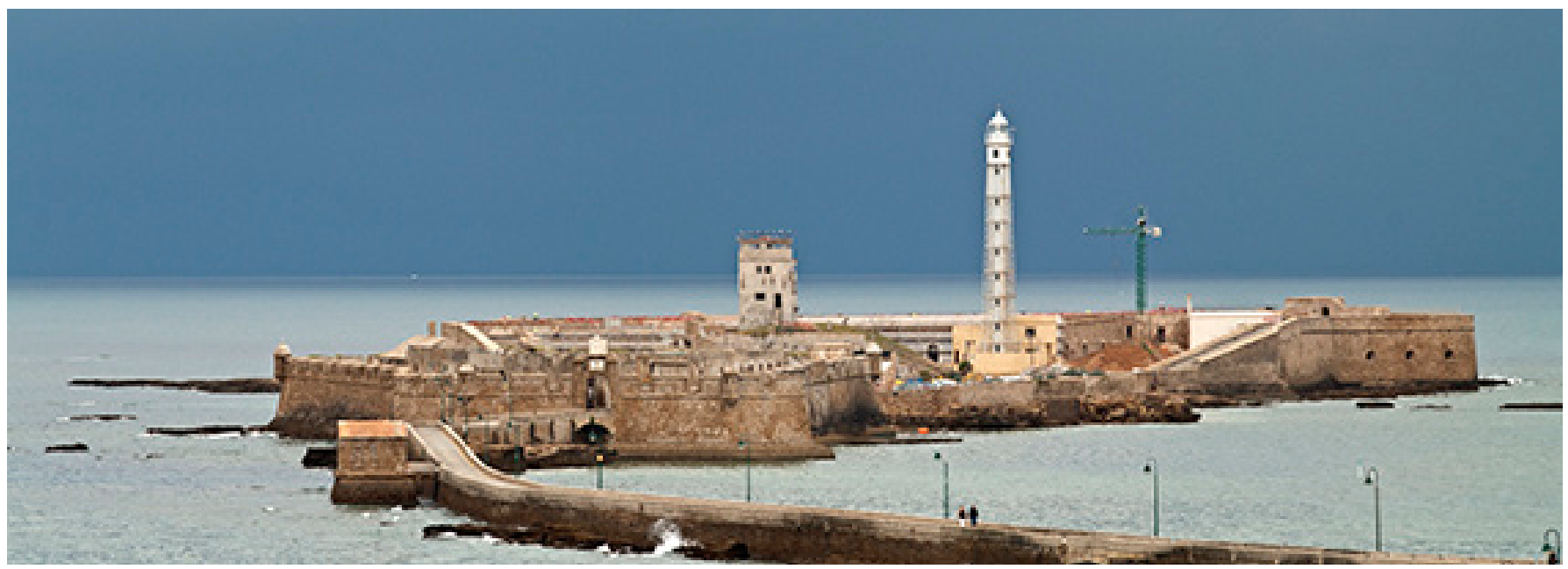

Vista general de castillo de San Sebastián (Cádiz), imagen dispobible en ReA | foto Fondo Gráfico IAPH (Isabel Dugo Cobacho)

del instituto, facetas de su labor que presentan un inestimable utilidad a la hora de constituir la historia de la institución.

En el Fondo Gráfico del IAPH encontramos también aquellas colecciones que se han agregado por la donación desinteresada de profesionales que a lo largo de su quehacer cotidiano fueron recopilando conformando un importante repertorio documental en torno al patrimonio, como son el fondo Becerra, de un gran valor documental y patrimonial por constituir una fuente de información del patrimonio arquitectónico de Andalucía occidental, los dibujos de Julio Alvar, en relación con el patrimonio etnológico, el fondo Salinas, donde se reúne un trascendental testimonio sobre nuestro paisaje, así como la donación hecha por el Gabinete Pedagógico de Bellas Artes de Sevilla, hoy desaparecido, el cual desarrolló una importante labor de difusión de esta provincia tanto entre los escolares como en la sociedad en general, y que pronto se incorporará a esta comunidad del ReA. Este tipo de colecciones presentan una mayor complejidad a la hora de ser almacenadas en el repositorio por las necesarias labores previas de digitalización de sus contenidos, catalogación y documentación.

\section{NOTA}

1. Léase, en este mismo número, la contribución El Repositorio de Activos Digitales (ReA) como herramienta para la difusión de la producción científica del IAPH, <www.iaph.es/revistaph/index.php/revistaph/article/ view/4623> [Consulta: 03/04/2020]

\section{BIBLIOGRAFÍA}

- SONTAG, S. (2006) Sobre la Fotografía. Madrid: Alfaguara, 2006, p. 40 